\title{
How TMT Knowledge Background Affects Corporate Social Responsibility and Firm Financial Performance?
}

\author{
Tong Liu' \& Yue'e $\mathrm{Li}^{1}$ \\ ${ }^{1}$ School of Economics and Management, China University of Geosciences, Wuhan, China \\ Correspondence: Tong Liu, School of Economics and Management, China University of Geosciences, No.68 \\ Zuoling Street, Wuhan, China. E-mail: 13628680170@163.com
}

Received: December 18, 2021

Accepted: January 20, $2022 \quad$ Online Published: January 26, 2022

doi:10.20849/abr.v7i1.984

URL: https://doi.org/10.20849/abr.v7i1.984

\begin{abstract}
The purpose of this study is to investigate the coupling relationship between corporate social responsibility (CSR) and firm financial performance, and consider top management team (TMT) knowledge background as moderators. Most of the existing studies focus on the one-way impact between CSR and firm financial performance. A few studies mention the coupling relationship between them. TMT knowledge background reflects leadership in organization which significantly impacts strategy of the company. With this concern, this study explores the relationships among these three factors and identified the relationships by an empirical study, using panel data of Chinese A-share listed companies from 2014 to 2019. 3SLS regression results show that CSR and firm financial performance do have coupling relationship. And firm financial performance has lag effect on CSR. Function background stands out of knowledge background to be a moderator between CSR and firm financial performance. Education background could also affect firm financial performance. With this view, sustainable development is becoming a trend, making profits and taking social responsibilities are both important. TMT structure should be improved to recruit experienced TMT members to help set strategy for the company. It conforms to the reform of specification of labor in China. Upgrading TMT education degree also makes sense for growth. Suggestions for promoting leadership in organization are given.
\end{abstract}

Keywords: top management team, knowledge background, corporate social responsibility, firm financial performance, coupling relationship

\section{Introduction}

As Peter Drucker said, 'Social responsibility and profitability are compatible, companies should translate social responsibility into business opportunities and profits.' Firm financial performance is important for both mangers and investors to evaluate firm's value and the operation situation. With this concern, the factors that may affect firm financial performance become a hot pot for business industries and academia. Different models have different factors, but the tendency is viewing factors from parallel to having priority. Leadership stands out in the Malcolm Baldrige model and becomes more and more important in firm financial performance measurement (Taouab and Issor, 2019). The Performance Pyramid proposed by Lynch and Cross (1992) inherits and puts leadership into corporate vision which makes the firm objectives' framework.

With the continuous development of economic globalization, the business environment of enterprises is becoming more and more complex. The top management team (TMT) of the enterprise plays an important role in the development of the enterprise which is directly related to the success or failure of business operation. Based on 'Upper Echelons Theory' (Hambrick and Masion, 1984), the demographic characteristic of TMT is a significant factor on firm financial performance. More recently, executive job demands which stem form three sets of factors: task challenges, performance challenges and executive operations are considered as a new moderator of 'Upper Echelons Theory' (Hambrick et al., 2005). It conforms to current situation where requirements for human resource are upgraded to a high level. Staff members' quality in company is emphasized widely which nourishes researches on TMT.

Company executives not only need to integrate the knowledge of workers in various fields, but also need to integrate various factors that affect the development of the organization, and make corresponding decisions based on their own experience, professional skills, etc., in order to achieve high performance for the organization and maximize corporate value. The level of knowledge background of TMT can be used as a manifestation of their 
abilities, which has an impact on people's cognitive styles and values. Knowledge background brings about the accumulation of education experience and function experience, which to some extent reflects people's recognition, capabilities and other characteristics. Therefore, the level of knowledge background exerts a certain degree of influence on the decision-making, leadership, and execution competencies of TMT, which are finally displayed through firm financial performance.

Most of the existing studies focus on the one-way impact between CSR and firm financial performance, while seldom studies point out actually these two factors have a coupling relationship. This paper verifies the coupling relationship between CSR and firm financial performance. It also considers TMT knowledge background as moderating variable to see its impact on CSR and firm financial performance. Panel data is applied in the empirical study of Chinese listed companies.

The structure of this paper will be organized as follows. Section 2 reviews the relevant literature and proposes the hypotheses. Section 3 presents the methodology used in this paper. Section 4 reports the empirical results and analysis. Section 5 summarizes this study and states some limitation of this study.

\section{Theoretical Framework and Hypotheses Development}

\subsection{Theoretical Foundations}

Exactly which members are covered by the TMT will directly determine the follow-up measure of moderating variables. From previous literatures, it can be found that the TMT is always considered as the chief executive officers (CEOs), general managers and/or presidents. Based on these previous studies and the reality in China, this study defines the TMT as the CEOs, general managers and board secretaries. This definition will be applied in TMT selection in this study.

And according to the definitions of TMT, the study on TMT characteristics is developed from different perspectives. The current studies mainly focus on the demographic characteristics while psychological dimensions are hard and complex to evaluate (Hambrick and Mason, 1984). Demographic characteristics reflect TMT's external characteristics that could be quantified, including education, work experience and tenure (Carpenter, 2002), overseas background including nationalities and international experiences (Nielsen, 2010), age status and shareholding status (Wang, 2016), functional experience, academic background, management experience, financial background, political background and gender (Cui et al., 2019). While psychological dimensions are internal ones related to personalities like the cognitive bases, values and perceptions that are inconvenient to measure (Hambrick and Mason, 1984). In this study, TMT demographic characteristics - education background and function background will be considered as moderators to reflect TMT knowledge background.

\subsection{CSR and Firm Financial Performance}

There should be some degree of coupling between firm financial performance and CSR interaction and influence on each other. Different kinds of approaches have been used to test this relationship. Zhang et al. (2013) construct a CSR comprehensive evaluation index and confirm that there is an interactive cross-period effect between CSR and firm financial performance excluding surplus management, using the System-GMM approach. CSR with a one-period lag has a significant positive effect on current period firm financial performance, and current period firm financial performance has a significant positive impact on current period CSR. Yin et al. (2014) use simultaneous equations and find that there is a significant cross-correlation between current period CSR and current period firm financial performance and the cross-period interaction between these two factors is also significant. Sun and Song (2021) also verify a significant coupling relationship between CSR and firm financial performance when they consider organizational redundancy as the threshold variable in the threshold model.

The impact of firm financial performance on CSR is more straightforward (Liu, 2020). After the firm financial performance is improved, the profit available for distribution will increase. All those involved are positive signals. If firm financial performance improves, enterprises will have more funds and motivation to fulfill CSR. But whether companies are willing to invest in CSR needs to be discussed by TMT. It is closely related to the future direction of development and the strategic goals, and it is also closely related to the strength of TMT's sense of social responsibility. Based on previous theoretical analysis, hypothesis 1 is proposed.

H1: There is a significant positive coupling relationship between CSR and firm financial performance, but the contribution of firm financial performance to CSR is more significant.

\subsection{Knowledge Background as Moderators}

\subsubsection{Education Background}

To some extent, education experience indicates a person's knowledge and skill base (Hambrick and Mason, 1984). 
TMT having higher education background will use some advanced management techniques and methods to improve firm financial performance (Graham and Harvey, 2002). He and Li (2005)'s study shows that there is a significant gap between the firm financial performance of TMT with low education and those with high education. TMT's formal educational achievement invariably exerts a positive influence on both firm financial performance level and growth. Generally speaking, TMT with high education also have a higher possibility possessing empathy on others that they are more willing to take CSR as their duty. Thus hypothesis $2 \mathrm{a}$ is proposed.

\section{H2a: Education background has positive moderating effect on CSR and firm financial performance.}

\subsubsection{Function Background}

Career experience can be expected to have a significant effect on the types of actions taken by TMT (Hambrick and Mason, 1984). The experiences TMT members accumulate during their careers form part of their emotions, preferences and perceptions, so they inevitably work with job orientations derived from experience in some of the career fields. This orientation toward professional experience does not directly dominate the socially responsible choices they make, but it does exert some degree of influence (Sun, 2009). It seems common to recruit TMT members having economics and management related working experience in most of the companies. But to what extent is it necessary to do so? Zhang et al. (2019) empirically find that TMT with economics and management professions has played a significant positive impact on CSR based on fixed-effects regression model. TMT with economics and management related working experience should be more alert to taking CSR as a strategy dealing with changes to promote firm financial performance. Hypothesis $2 b$ is proposed to test the influencing mechanism of function background.

\section{H2b: Function background has positive moderating effect on CSR and firm financial performance.}

\section{Methodology}

\subsection{Data Collection}

This paper chooses Chinese A-share listed companies scored by RKS from 2014 to 2019. To avoid sample selection bias, this paper has selected the samples according to the following principles. First, referring to the existing studies, since the financial statement system of financial and insurance enterprises is different from others', we exclude finance and insurance companies. Second, we exclude ST and ST* companies because these companies in the current year face more serious abnormal business disturbance factors. Third, in order to avoid outliers, this paper excludes companies with abnormal financial status and relevant missing data. Finally, taking into account the influence of extreme values, this paper winsorizes all continuous variables at $1 \%$ quantile and $99 \%$ quantile.

\subsection{Measures}

\subsubsection{Dependent Variable}

The disclosure period of CSR reports of listed companies in China is not long, and the theoretical construction of CSR is not complete. Many domestic scholars define CSR qualitatively or quantitatively from different dimensions, but the degree of bias in all aspects of CSR evaluation is different, which causes the evaluation results to become subjective and lack of completeness. Therefore, in order to maintain objectivity, this paper adopts the CSR rating scores of Chinese listed companies issued by RKS, a domestically recognized third-party evaluation agency, as a proxy to evaluate the degree of CSR.

\subsubsection{Independent Variable}

Firm financial performance is a multi-dimensional and complex concept, which is usually used to measure the effectiveness of corporate management. Chinese and foreign scholars tend to use accounting indicators such as return on assets (ROA), return on equity (ROE) and operating profit to describe the historical performance of enterprises, or use Tobin's $Q$ value and market value to describe the future operating conditions of enterprises, because these two types of indicators reflect the short-term profitability and long-term profit potential of the enterprise. However, common accounting metrics such as ROA and ROE are susceptible to the effects of surplus management. Tobin's Q includes the company's past performance in the market, and also reflects the company's future growth prospects and stakeholder concerns and the level of stakeholder interest (Wei and $\mathrm{Hu}, 2021$ ). This paper selects Tobin's Q as the initial indicator of firm financial performance which is calculated as market value divided by total assets in CSMAR database.

\subsubsection{Moderating Variables}

Knowledge background contains education background and function background, which reflect TMT inherent executive abilities as a whole. 
The proportion of the TMT with a master's degree or above is used to evaluate the level of education of TMT.

The proportion of the TMT with related economics and management working experience is used to evaluate the level of function of TMT.

All the variables in this study are concluded in Table 1.

Table 1. Variables definition

\begin{tabular}{lcc}
\hline \multicolumn{1}{c}{ Name of variable } & Variable & Calculation of variable \\
\hline Corporate Social Responsibility & CSR & RKS rating scores \\
\hline Tobin's Q Ratio & TobinQ & $\frac{\text { Market value }}{\text { Total assets }}$ \\
\hline Education Background & Eduback & $\frac{\text { Master and above number }}{\text { Total TMT number }}$ \\
\hline Function Background & Funback & Economics and management related working experience number \\
\cline { 2 - 3 } & Size & Total TMT number \\
\hline Enterprise Size & Gov & Ln(total assets) \\
\hline Enterprise Property- & State - owned shares \\
Ratio of state-owned shares & Ane & Total equity \\
\hline Enterprise Age & Year & Dummy variable \\
\hline Industry & & Dummy variable \\
\hline Year & &
\end{tabular}

\subsection{Methods}

There should be a two-way causal relationship between CSR and firm financial performance, and a single equation model cannot completely describe the relationship between these two variables. So simultaneous equations are used to solve this problem.

Model (1) is simultaneous equations for verifying hypothesis 1, that is, testing the coupling relationship between CSR and firm financial performance.

$$
\left\{\begin{array}{l}
C S R=\lambda_{0}+\lambda_{1} \text { Tobin } Q+\theta^{\prime} \sum \text { controls }+\zeta \\
\text { TobinQ }=\eta_{0}+\eta_{1} C S R+\theta^{\prime} \sum \text { controls }+\zeta
\end{array}\right.
$$

Then this paper sequentially adds knowledge background as moderating variables to the study of CSR and firm financial performance.

Model (2) is set considering education background as a moderator with TobinQ on CSR.

$$
\text { CSR }=\alpha_{0}+\alpha_{1} \text { Tobin } Q+\alpha_{2} \text { Eduback }+\alpha_{3} \text { Tobin } Q * \text { Eduback }+\theta^{\prime} \sum \text { controls }+\zeta
$$

Model (3) is set considering education background as a moderator with CSR on TobinQ.

$$
\text { Tobin } Q=\beta_{0}+\beta_{1} C S R+\beta_{2} E d u b a c k+\beta_{3} C S R * \text { Eduback }+\theta^{\prime} \sum \text { controls }+\zeta
$$

Model (2) and Model (3) are combined to test hypothesis 2a.

Model (4) is set considering function background as a moderator with TobinQ on CSR.

$$
\text { CSR }=\alpha_{0}+\alpha_{1} \text { Tobin } Q+\alpha_{2} \text { Funback }+\alpha_{3} \text { Tobin } Q * \text { Funback }+\theta^{\prime} \sum \text { controls }+\zeta
$$

Model (5) is set considering function background as a moderator with CSR on TobinQ.

$$
\text { Tobin } Q=\beta_{0}+\beta_{1} C S R+\beta_{2} \text { Funback }+\beta_{3} \text { CSR } * \text { Funback }+\theta^{\prime} \sum \text { controls }+\zeta
$$

Model (4) and Model (5) are combined to test hypothesis $2 \mathrm{~b}$. 


\section{Results and Analysis}

\subsection{Descriptive Statistics Analysis}

All the variables are matched in Stata 16.0 and 534 pieces of data are reserved. It could be seen in Table2, the mean score of CSR is 44.688 which is under 50 out of 100 , indicating the overall fulfillment of CSR of Chinese A-share listed companies is not high. The overall education background of TMT is $52.4 \%$, more than half of the TMT members are masters or above degree holders. TMT graces highly educated people. The overall function background of TMT is $97.9 \%$, almost $100 \%$ of the TMT members have economics and management related working experience. It is crucial for recruitment of TMT to have these kinds of experiences.

Table 2. Descriptive statistics

\begin{tabular}{lllllll}
\hline variable & $\mathrm{N}$ & mean & $\mathrm{p} 50$ & $\mathrm{sd}$ & $\min$ & $\max$ \\
\hline CSR & 534 & 44.688 & 42.254 & 12.677 & 20.600 & 80.007 \\
\hline TobinQ & 534 & 1.105 & 0.769 & 1.021 & 0.121 & 7.400 \\
\hline Eduback & 534 & 0.524 & 0.500 & 0.275 & 0.091 & 1.000 \\
\hline Funback & 534 & 0.979 & 1.000 & 0.058 & 0.667 & 1.000 \\
\hline Size & 534 & 23.486 & 23.383 & 1.234 & 20.924 & 26.380 \\
\hline Age & 534 & 19.117 & 19.040 & 5.194 & 7.080 & 31.750 \\
\hline Gov & 534 & 34.278 & 36.430 & 21.645 & 0.950 & 76.500 \\
\hline
\end{tabular}

\subsection{Correlation Analysis}

The Pearson correlation coefficients analyze the existence of related variables and the correlation between the positive and negative analysis. It could be found most of the relationships are significant in Table 3 . There is a significant negative correlation between CSR and firm financial performance at the $1 \%$ level, which seems contrary to the main hypothesis. It is because Pearson correlation analysis only considers the relationship between CSR and TobinQ, and drops the control variables. It could only be a reference since the main hypothesis regressions will include the control variables. So it is common to have difference which does not deny the hypothesis. And it's necessary to take control variables into account to test the main hypothesis. Education background has significant impact on CSR, while function background has significant impact on TobinQ. Most of the control variables are significant, indicating the selection of control variables is correct.

Table 3. Pearson correlation analysis

\begin{tabular}{|c|c|c|c|c|c|c|c|}
\hline & CSR & TobinQ & Eduback & Funback & Size & Age & Gov \\
\hline CSR & 1.000 & & & & & & \\
\hline \multirow[t]{2}{*}{ TobinQ } & $-0.232 * * *$ & 1.000 & & & & & \\
\hline & 0.0000 & & & & & & \\
\hline \multirow[t]{2}{*}{ Eduback } & $0.082 *$ & -0.048 & 1.000 & & & & \\
\hline & 0.0582 & 0.2712 & & & & & \\
\hline \multirow[t]{2}{*}{ Funback } & -0.032 & $0.095^{* *}$ & 0.001 & 1.000 & & & \\
\hline & 0.4568 & 0.0281 & 0.9773 & & & & \\
\hline Size & $0.512 * * *$ & $-0.520 * * *$ & $0.230 * * *$ & 0.006 & 1.000 & & \\
\hline
\end{tabular}




\begin{tabular}{llllllll}
\hline & 0.0000 & 0.0000 & 0.0000 & 0.8941 & & & \\
\hline Age & -0.067 & $-0.211^{* * *}$ & $0.081^{*}$ & -0.011 & -0.034 & 1.000 & \\
& 0.1220 & 0.0000 & 0.0614 & 0.8003 & 0.4357 & & \\
\hline \multirow{2}{*}{ Gov } & $0.090^{* *}$ & $-0.166^{* * *}$ & $0.098^{* *}$ & $-0.090^{* *}$ & $0.193^{* * *}$ & -0.006 & 1.000 \\
& 0.0369 & 0.0001 & 0.0230 & 0.0367 & 0.0000 & 0.8961 & \\
\hline
\end{tabular}

Note: $* \mathrm{p}<0.1, * * \mathrm{p}<0.05, * * * \mathrm{p}<0.01$

\subsection{Coupling Regression}

3SLS is a complete information estimation method for simultaneous equation models. The estimation result of this method has better asymptotic validity than the 2SLS estimation under certain conditions. Because more information is used in the 3SLS estimation process than the 2SLS method. 3SLS regression procedure and results are shown in Table4. CSR's impact factor on TobinQ and TobinQ's impact factor on CSR are significantly positive, indicating they have positive coupling relationship. Companies can fully utilize their profits to fulfill their social responsibility, and at the same time, they can continuously promote their financial performance by gaining more social recognition for their higher level of social responsibility. They obtain more social recognition and continuously promote the performance and achieve the overall interests of stakeholders. Compared to the extent of CSR's impact on TobinQ, TobinQ produces a stronger impact on CSR. This indicates that TobinQ has a stronger influence on CSR, which is consistent with the entry point of this study and indirectly explains the discrepancy between the existing research findings on CSR and TobinQ. In summary, hypothesis 1 is verified.

Table 4. Coupling relationship

\begin{tabular}{|c|c|c|c|c|c|c|}
\hline & OLS & & 2SLS & & $3 \mathrm{SLS}$ & \\
\hline & TobinQ & CSR & TobinQ & CSR & TobinQ & CSR \\
\hline \multirow[t]{2}{*}{ CSR } & $.0071098 * * *$ & & $.0071098 * * *$ & & $.0140736 * * *$ & \\
\hline & $(2.66)$ & & $(2.82)$ & & $(5.38)$ & \\
\hline \multirow[t]{2}{*}{ TobinQ } & & $1.451934 * * *$ & & $1.451934 * * *$ & & $2.87435^{* * *}$ \\
\hline & & $(2.64)$ & & $(2.60)$ & & $(5.35)$ \\
\hline
\end{tabular}

Note: $* \mathrm{p}<0.1, * * \mathrm{p}<0.05, * * * \mathrm{p}<0.01$

\subsection{Moderating Regressions}

Since the performance of CSR in the sample data is directly scored as a continuous independent variable, this paper centralizes all the variables and a hierarchical regression method is used to analyze the moderating effect. Regression results are shown in Table5, the interaction item of TobinQ and function background has a positive significant effect on CSR. H2b is verified that having economics and management related working experience could help improve firm financial performance and then improve CSR. The education background has a positive significant effect on TobinQ. TMT members having higher education experience encouraged them to help improve firm financial performance. While the interaction item of CSR and education background is not significant, which means education background is not a moderator between CSR and TobinQ. H2a is refused. 
Table 5. Regression results-TobinQ

\begin{tabular}{|c|c|c|c|c|c|c|}
\hline & (1) & (1) & (1) & (2) & (2) & (2) \\
\hline & CSR & CSR & CSR & TobinQ & TobinQ & TobinQ \\
\hline \multirow[t]{2}{*}{ TobinQ } & $1.452 * * *$ & $1.526 * *$ & $1.108^{*}$ & & & \\
\hline & (2.64) & $(2.34)$ & (1.89) & & & \\
\hline \multirow[t]{2}{*}{ Eduback } & & -2.649 & & & & \\
\hline & & $(-1.26)$ & & & & \\
\hline \multirow[t]{2}{*}{ TobinQ*Eduback } & & -1.425 & & & & \\
\hline & & $(-0.66)$ & & & & \\
\hline \multirow[t]{2}{*}{ Funback } & & & 8.070 & & & \\
\hline & & & $(0.86)$ & & & \\
\hline \multirow[t]{2}{*}{ TobinQ*Funback } & & & $20.552 *$ & & & \\
\hline & & & $(1.86)$ & & & \\
\hline \multirow[t]{2}{*}{ CSR } & & & & $0.007 * * *$ & $0.008 * *$ & $0.007 * * *$ \\
\hline & & & & $(2.66)$ & $(2.41)$ & $(2.65)$ \\
\hline \multirow[t]{2}{*}{ Eduback } & & & & & $0.331 * *$ & \\
\hline & & & & & $(2.56)$ & \\
\hline \multirow[t]{2}{*}{ CSR*Eduback } & & & & & -0.010 & \\
\hline & & & & & $(-1.00)$ & \\
\hline \multirow[t]{2}{*}{ Funback } & & & & & & 0.753 \\
\hline & & & & & & $(1.55)$ \\
\hline \multirow[t]{2}{*}{ CSR*Funback } & & & & & & -0.025 \\
\hline & & & & & & $(-0.71)$ \\
\hline \multirow[t]{2}{*}{ Size } & $5.433 * * *$ & $5.708 * * *$ & $5.462 * * *$ & $-0.361 * * *$ & $-0.399 * * *$ & $-0.365 * * *$ \\
\hline & (13.24) & (11.46) & (13.18) & $(-12.46)$ & $(-11.15)$ & $(-12.50)$ \\
\hline \multirow[t]{2}{*}{ Age } & -0.072 & -0.119 & -0.063 & $-0.029 * * *$ & $-0.030 * * *$ & $-0.029 * * *$ \\
\hline & $(-0.82)$ & $(-1.15)$ & $(-0.71)$ & $(-4.73)$ & $(-4.16)$ & $(-4.76)$ \\
\hline \multirow[t]{2}{*}{ Gov } & 0.019 & -0.002 & 0.017 & -0.002 & -0.003 & -0.002 \\
\hline & $(0.93)$ & $(-0.10)$ & $(0.87)$ & $(-1.26)$ & $(-1.63)$ & $(-1.22)$ \\
\hline \multirow[t]{2}{*}{ _cons } & $-97.842 * * *$ & $-82.468 * * *$ & $-106.672 * * *$ & $13.078 * * *$ & $11.149 * * *$ & $12.390 * * *$ \\
\hline & $(-6.48)$ & $(-5.90)$ & $(-6.19)$ & (13.59) & (12.33) & $(11.77)$ \\
\hline $\mathrm{N}$ & 696 & 534 & 696 & 696 & 534 & 696 \\
\hline $\mathrm{F}$ & 14.427 & 11.727 & 13.472 & 28.640 & 20.957 & 26.393 \\
\hline $\mathrm{r} 2$ & 0.320 & 0.335 & 0.325 & 0.484 & 0.474 & 0.486 \\
\hline Year & Yes & Yes & Yes & Yes & Yes & Yes \\
\hline Industry & Yes & Yes & Yes & Yes & Yes & Yes \\
\hline
\end{tabular}

Note: $\mathrm{t}$ statistics in parentheses, $* \mathrm{p}<0.1, * * \mathrm{p}<0.05$, *** $\mathrm{p}<0.01$

\subsection{Robustness Tests}

\subsubsection{Change Variable}

Firm financial performance indicator-TobinQ, is replaced by ROA to do the robustness test. Generally speaking, CSR and ROA have the same coupling relationship with CSR and TobinQ. But the relationship is not as stable as CSR and TobinQ, especially when the ROA is independent variable. CSR has smaller influence on ROA compared 
to TobinQ as independent variable. It might be the reason that ROA is influenced by the effects of surplus management. However, it deepens the accuracy in this paper to use TobinQ as firm financial performance indicator in the previous main study.

\subsubsection{Lag TobinQ}

TobinQ is lagged by one period to see if lag effect exists. CSR's impact factor on 1.TobinQ (lag TobinQ) and 1.TobinQ's impact factor on CSR are still significantly positive, indicating they have stable positive coupling relationship. And the coupling relationship has lag effect.

The regression results are the same as before. The interaction item of 1.TobinQ and function background has a positive significant effect on CSR. H2b is further verified under lag effect. The education background has a positive significant effect on 1.TobinQ. TMT members having higher education experience are capable to help improve long-term financial performance.

\section{Discussion}

It is verified that CSR and TobinQ have coupling relationship on current period and TobinQ has lag effect. Taking CSR brings reputation to the company, and helps gain intangible assets and make profits. When the company has a stable profit gain, it will be more willing to take CSR. It is a virtuous cycle. And it will be a trend that firm financial performance and CSR are of parallel importance in company's strategy. Setting sustainable development strategy is urgent and necessary.

Leadership is of high importance in the organization. TMT function background is a crucial moderator between firm financial performance and CSR. It is recommended to recruit people with economics and management related working experience to be TMT members or to train people with potential to become TMT members to have these kinds of experience. China is undergoing a period where division of labor based on specialization is of high importance. The government is taking actions to reform the education from junior school and calling for hiring professional people to do professional work. Education as a demographic characteristic also initially represents one's recognition, which has impact on TMT decision-making process. It's also a crucial factor when considering TMT structure. Knowledge background is not purely demographic characteristics, it also reflects one's psychological characteristics to some extent. Education background and function background relate to one's experience and build one's recognition and value which deserves researching in TMT study.

Although the author has tried her best on this study, there are still some limitations. The selection of control variables could be expanded for better regression results. Unfortunately, not all the hypotheses are verified maybe due to the data limitation and data processing. There might be other factors reflecting TMT knowledge background, like overseas background or something else. Further studies could view from these points to make progress.

\section{References}

Carpenter, M. A. (2002). The Implications of Strategy and Social Context for the Relationship between Top Management Team Heterogeneity and Firm Performance. Strategic Management Journal, 23(3), 275-284. https://doi.org/10.1002/smj.226

Cheng, T. W., Chan, Y. K., \& Leung, T. Y. (2010). Management Demography and Corporate Performance: Evidence from China. International Business Review, 19(3), 261-275. https://doi.org/10.1016/j.ibusrev.2009.12.007

Cui, Y., Zhang, Y., Guo, J., Hu, H., \& Meng, H. (2019). Top management team knowledge heterogeneity, ownership structure and financial performance: Evidence from Chinese IT listed companies. Technological Forecasting and Social Change, 140(C), 14-21. https://doi.org/10.1016/j.techfore.2018.12.008

Graham, J. R., \& Harvey, C. R. (2002). How Do Cfos Make Capital Budgeting and Capital Structure Decisions?. Applied Corporate Finance, 15(1), 8-23. https://doi.org/10.1111/j.1745-6622.2002.tb00337.x

Hambrick, D. C., \& Mason, P. A. (1984). Upper echelons: the organization as a reflection of its top managers. Academy of Management Review, 9(2), 193-206. https://doi.org/10.2307/258434

Hambrick, D. C., Finkelstein, S., \& Mooney, A. C. (2005). Executive Job Demands: New Insights for Explaining Strategic Decisions and Leader Behaviors. Academy of Management Review, 30(3), 472-491. https://doi.org/10.5465/amr.2005.17293355

He, X. G., \& Li, X. C. (2005). Entrepreneurial Competence and Enterprises' Growth: An Empirical Study in China. Economic Research Journal, (10), 101-111.

Liu, Y. R. (2020). An Empirical Study on the Relationship between Corporate Social Responsibility and Financial 
Performance. Management and Administration, (6), 52-61.

Lynch, R., \& Cross, K. F. (1991). Measure Up!: Yardsticks for Continuous Improvement.

Nielsen, S. (2010). Top Management Team Internationalization and Firm Performance: The Mediating Role of Foreign Market Entry. MIR: Management International Review, 50(2), 185-206. https://doi.org/10.1007/s11575-010-0029-0

Sun, D. S. (2009). Top Manamegment Team and Corporate Social Responsibility: Upper Echelons Perspective. Science of Science and Management of S.\& T., 30(4), 188-193.

Sun, X. Y., \& Song, Y. (2021). Financial Performance, Organizational Redundancy and Corporate Social Responsibility. Statistics \& Decision, 37(16), 184-188.

Taouab, O., \& Issor, Z. (2019). Firm Performance: Definition and Measurement Models. European Scientific Journal, 15(1), 93-106. https://doi.org/10.19044/esj.2019.v15n1p93

Wang, Y. (2016). The Interrelationship Existing in Top Management Team, Organization Change and Technology Innovation Strategy---A Theoretical Review. Journal of Technical Economics \& Management, (2), 40-44.

Wei, Y. Y., \& Hu, C. (2021). Research on the Relationship between Environmental Policy, Corporate Social Responsibility and Financial Performance---Based on an Empirical Analysis of Companies that Violate Environmental Regulations in Heavy Polluting Industries. Journal of East China University of Science and Technology (Social Science Edition), 36(3), 125-133.

Yin, K. G., Liu, X. Q., \& Chen, H. D. (2014). Study on the Relationship between Corporate Social Responsibility and Financial Performance from the Endogenous Perspective---Evidence from Chinese Listed Companies. China Soft Science, (6), 98-108.

Zhang, Y. K., Li, Y. N., Li, B., \& Zeng, Y. T. (2019). Senior Managers' Professional Background, Academic Characteristics and Corporate Social Responsibility. Hubei Social Sciences, (11), 78-89.

Zhang, Z. G., Jin, X. C., \& Li, G. Q. (2013). An Empirical Study on the Interactive and Inter-Temporal Influence between Corporate Social Responsibility and Corporate Financial Performance. Accounting Research, (8), 32-39, 96.

\section{Copyrights}

Copyright for this article is retained by the author(s), with first publication rights granted to the journal.

This is an open-access article distributed under the terms and conditions of the Creative Commons Attribution license (http://creativecommons.org/licenses/by/4.0/). 